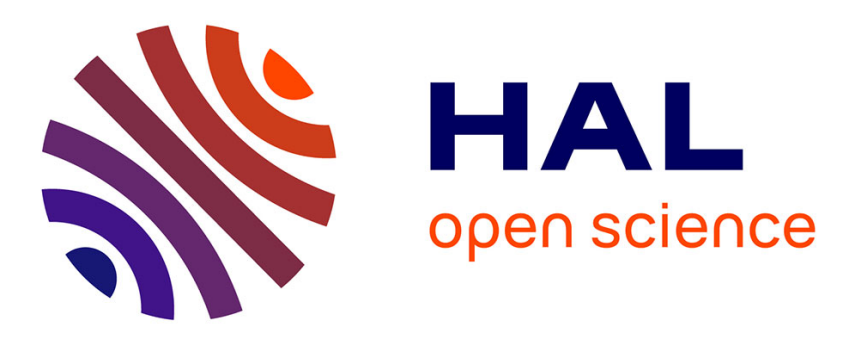

\title{
The mitogenome of Hydropsyche pellucidula (Hydropsychidae): first gene arrangement in the insect order Trichoptera
}

Benjamin Linard, P. Arribas, C. Andújar, A. Crampton-Platt, A. P. Vogler

\section{- To cite this version:}

Benjamin Linard, P. Arribas, C. Andújar, A. Crampton-Platt, A. P. Vogler. The mitogenome of Hydropsyche pellucidula (Hydropsychidae): first gene arrangement in the insect order Trichoptera. Mitochondrial DNA Part A, 2016, 28 (1), pp.71-72. 10.3109/19401736.2015.1110803 . hal-01636904

\section{HAL Id: hal-01636904 https://hal.science/hal-01636904}

Submitted on 20 Jan 2019

HAL is a multi-disciplinary open access archive for the deposit and dissemination of scientific research documents, whether they are published or not. The documents may come from teaching and research institutions in France or abroad, or from public or private research centers.
L'archive ouverte pluridisciplinaire HAL, est destinée au dépôt et à la diffusion de documents scientifiques de niveau recherche, publiés ou non, émanant des établissements d'enseignement et de recherche français ou étrangers, des laboratoires publics ou privés. 


\section{The mitogenome of Hydropsyche pellucidula (Hydropsychidae): first}

\section{gene arrangement in the insect order Trichoptera}

Linard B. ${ }^{1}$, Arribas P. ${ }^{1,2}$, Andújar C. ${ }^{1,2}$, Crampton-Platt A. ${ }^{1,3}$, Vogler A.P. ${ }^{1,2}$

${ }^{1}$ Department of Life Sciences, Natural History Museum, Cromwell Road, London SW7 5BD, UK,

${ }^{2}$ Department of Life Sciences, Imperial College London, Silwood Park Campus, Ascot SL5 7PY, UK,

${ }^{3}$ Department of Genetics, Evolution and Environment, University College London, Gower Street, London WC1E 6BT, UK

* Corresponding authors: Benjamin Linard b.linard@nhm.ac.uk; Paula Arribas p.arribas@nhm.ac.uk 


\begin{abstract}
We describe the mitochondrial genome of Hydropsyche pellucidula Curtis 1834, which is the first described for the suborder Annulipalpia and the first in the order Trichoptera to show a noncanonical gene order. The mitogenome was obtained by de novo assembly of shotgun sequenced total genomic DNA using Illumina Miseq technology, which produced an average coverage of $115 x$ and a minimum coverage of $48 x$. The mitochondrial genome includes 13 protein-coding genes, 2 rRNAs, 22 tRNAs. The genome is characterized by a rearrangement in the relative position of protein-coding and ribosomal genes. This mitogenome sequence will be useful for studies of the family Hydropsychidae, which is commonly used for freshwater pollution biomonitoring.
\end{abstract}

\title{
Keywords
}

Mitochondrial rearrangement, mitochondrial metagenomics, Hydropsychoidae, biomonitoring

\section{Main text}

The insect order Trichoptera contains around 12,000 described species (Mackay \& Wiggins 1979). Both the aquatic larvae and terrestrial adult stages are essential components of aquatic and riparian communities and are used for biological assessment of water quality (Mackay \& Wiggins, 2003; de Moor \& Ivanov, 2008). We sequenced the mitogenome of Hydropsyche pellucidula BMNH-1425186 (Trichoptera: Hydropsychidae). The high bioindicator value of the genus Hydropsyche (Tszydel et al. 2015), makes this mitogenome a useful tool for biomonitoring approaches.

The voucher specimen was a larva manually collected from Adam's Pond, Richmond Park, London, UK. It was morphologically identified and deposited in the Natural History Museum of London (voucher code BMNH 1425186). The mitogenome was de novo assembled from a metagenomic library containing other aquatic macroinvertebrates following the mitochondrial metagenomics (MMG) approach (Gillett et al. 2014; Tang et al. 2014; Crampton-Platt et al. 2015). The mitochondrial 
contig of Hydropsyche pellucidula was identified through its cox1 gene (barcode region) obtained by Sanger sequencing and by its $99.6 \%$ similarity to another barcode from Múrria et al., 2010 (HM134820). Gene annotations were predicted using MITOS (Bernt et al. 2013) and were manually refined.

The resulting mitogenome is $25,004 \mathrm{bp}$ long with an even read coverage of $115 \mathrm{x}$ on average (min: 48x; max: 280x). We identified 13 protein-coding genes, 2 rRNAs and 22 tRNAs and a particularly long control region ( $8 \mathrm{~kb})$. A terminal AT rich region did not allow us to circularize the genome with confidence. The gene order differs from canonical insect mitochondria. The $r r n S$, generally located between the $r r n L$ and the control region is displaced to a region between cob and nad1 and is flanked by two regions of around 600 and $800 \mathrm{bp}$ for which homology could not be established. Additionally, two tRNAs (trnP, trnl) are also found in non-canonical positions.

The sequence was validated by the construction of a phylogenetic tree for the order Trichoptera based on protein coding and rRNA genes from all complete or nearly complete mitogenomes and transcriptomes retrieved from GeneBank (September 2015; Benson et al., 2014). The dataset included 9 different species sharing a set of mitochondrial loci (atp6, cob, cox1, cox2, cox3, nad1, nad3, nad4 and $r r n L)$. Three Lepidoptera genomes were selected as outgroups. Multiple alignments were built for each locus with MAFFT (Katoh \& Standley 2013) and a maximum-likelihood phylogenetic analysis was conducted in RAxML-HPC2 (Stamatakis 2006) on the CIPRES server (Miller et al. 2010). The best tree was selected over 100 alternative runs, using a GTR-cat model and node support was calculated with 10000 bootstrap replicates.

As expected, Hydropsyche pellucidula is placed in the suborder Annulipalpia (Figure 1), which is recovered as monophyletic. In contrast, the suborder Integripalpia appears to be paraphyletic and contentious as previously reported (Ivanov 2002; Kjer et al. 2002). The tree is also consistent with the recent phylogenomic analysis of Misof et al., 2014. The rearrangement cannot be assigned to a 
specific phylogenetic level, as other Annulipalpia data are based on transcriptomes and unknown gene order. The mitogenome was deposited in Genbank: KT876876.

\section{Acknowledgments}

We would like to thank Alex Aitken, Kevin Hopkins and Peter Foster (Natural History Museum), for their technical assistance and Núria Bonada and Félix Picazo for her help in morphological identification. PA, CA collected the specimen. PA performed wet lab work. BL, ACP ran the bioinformatic analyses. BL wrote the manuscript and APV supervised the project. This work was founded by the NHM Biodiversity Initiative. PA was supported by a postdoctoral grant from The Royal Society (Newton International Program, UK).

\section{Declaration of Interest}

The authors report no conflicts of interest. The authors alone are responsible for the content and writing of the article.

\section{References}

Benson, D.A. et al., 2014. GenBank. Nucleic Acids Research, 42(D1).

Bernt, M. et al., 2013. MITOS: Improved de novo metazoan mitochondrial genome annotation. Molecular Phylogenetics and Evolution, 69(2), pp.313-319.

Crampton-Platt, A. et al., 2015. Soup to Tree: The Phylogeny of Beetles Inferred by Mitochondrial Metagenomics of a Bornean Rainforest Sample. Molecular biology and evolution, p.msv111-. Available at: http://mbe.oxfordjournals.org/content/early/2015/06/12/molbev.msv111 [Accessed June 30, 2015].

Gillett, C.P.D.T. et al., 2014. Bulk de novo mitogenome assembly from pooled total DNA elucidates the phylogeny of weevils (Coleoptera: Curculionoidea). Molecular Biology and Evolution, 31, pp.2223-2237. Available at:

http://mbe.oxfordjournals.org/content/early/2014/05/06/molbev.msu154.abstract [Accessed May 28, 2014].

Ivanov, V.D., 2002. Contribution to the Trichoptera phylogeny: new family tree with consideration of Trichoptera-Lepidoptera relations W. Mey, ed., Nova Supplementa Entomologica, Keltern. 
Katoh, K. \& Standley, D.M., 2013. MAFFT multiple sequence alignment software version 7: Improvements in performance and usability. Molecular Biology and Evolution, 30(4), pp.772780.

Kjer, K.M., Blahnik, R.J. \& Holzenthal, R.W., 2002. Phylogeny of caddisflies (Insecta, Trichoptera). Zoologica Scripta, 31(1), pp.83-91. Available at: http://doi.wiley.com/10.1046/j.03003256.2001.00079.x [Accessed September 21, 2015].

Mackay, R.J. \& Wiggins, G.B., 1979. Ecological Diversity in Trichoptera. Annual Review of Entomology, 24(1), pp.185-208. Available at: http://dx.doi.org/10.1146/annurev.en.24.010179.001153.

Miller, M.A., Pfeiffer, W. \& Schwartz, T., 2010. Creating the CIPRES Science Gateway for inference of large phylogenetic trees. In 2010 Gateway Computing Environments Workshop, GCE 2010.

Misof, B. et al., 2014. Phylogenomics resolves the timing and pattern of insect evolution. Science, 346(6210), pp.763-767. Available at: http://www.sciencemag.org/content/346/6210/763.full [Accessed November 6, 2014].

De Moor, F.C. \& Ivanov, V.D., 2008. Global diversity of caddisflies (Trichoptera: Insecta) in freshwater. In E. V Balian et al., eds. Freshwater Animal Diversity Assessment SE - 41. Developments in Hydrobiology. Springer Netherlands, pp. 393-407. Available at: http://dx.doi.org/10.1007/978-1-4020-8259-7_41.

Múrria, C. et al., 2010. Genetic and morphological approaches to the problematic presence of three Hydropsyche species of the pellucidula group (Trichoptera: Hydropsychidae) in the westernmost Mediterranean Ba. Aquatic Insects, 32(2), pp.85-98.

R J Mackay, and \& Wiggins, G.B., 2003. Ecological Diversity in Trichoptera. Available at: http://www.annualreviews.org/doi/abs/10.1146/annurev.en.24.010179.001153?journalCode= ento [Accessed September 10, 2015].

Stamatakis, A., 2006. RAxML-VI-HPC: Maximum likelihood-based phylogenetic analyses with thousands of taxa and mixed models. Bioinformatics, 22(21), pp.2688-2690.

Tang, M. et al., 2014. Multiplex sequencing of pooled mitochondrial genomes--a crucial step toward biodiversity analysis using mito-metagenomics. Nucleic Acids Research, p.gku917-. Available at: http://nar.oxfordjournals.org/content/early/2014/10/07/nar.gku917.abstract [Accessed October 8, 2014].

Tszydel, M. et al., 2015. Assessment of water quality in urban streams based on larvae of Hydropsyche angustipennis (Insecta, Trichoptera). Environmental science and pollution research international. Available at: http://www.ncbi.nlm.nih.gov/pubmed/25982980 [Accessed September 10, 2015]. 
Figure 1: Phylogeny of the order Trichoptera based on 9 mitochondrial loci (atp6, cob, cox1, cox2, $\operatorname{cox} 3, n d 1, n d 3, n d 4$ and $r r n L)$. The new mitogenome is highlighted with a white box. Suborders are delimited by red (Annulipalpia) and blue (Integripalpia) backgrounds. Trichoptera species with a complete mitochondrial genome are marked by an asterisk. All other species are based on transcriptomic data, i.e. their relative gene order remains unknown.

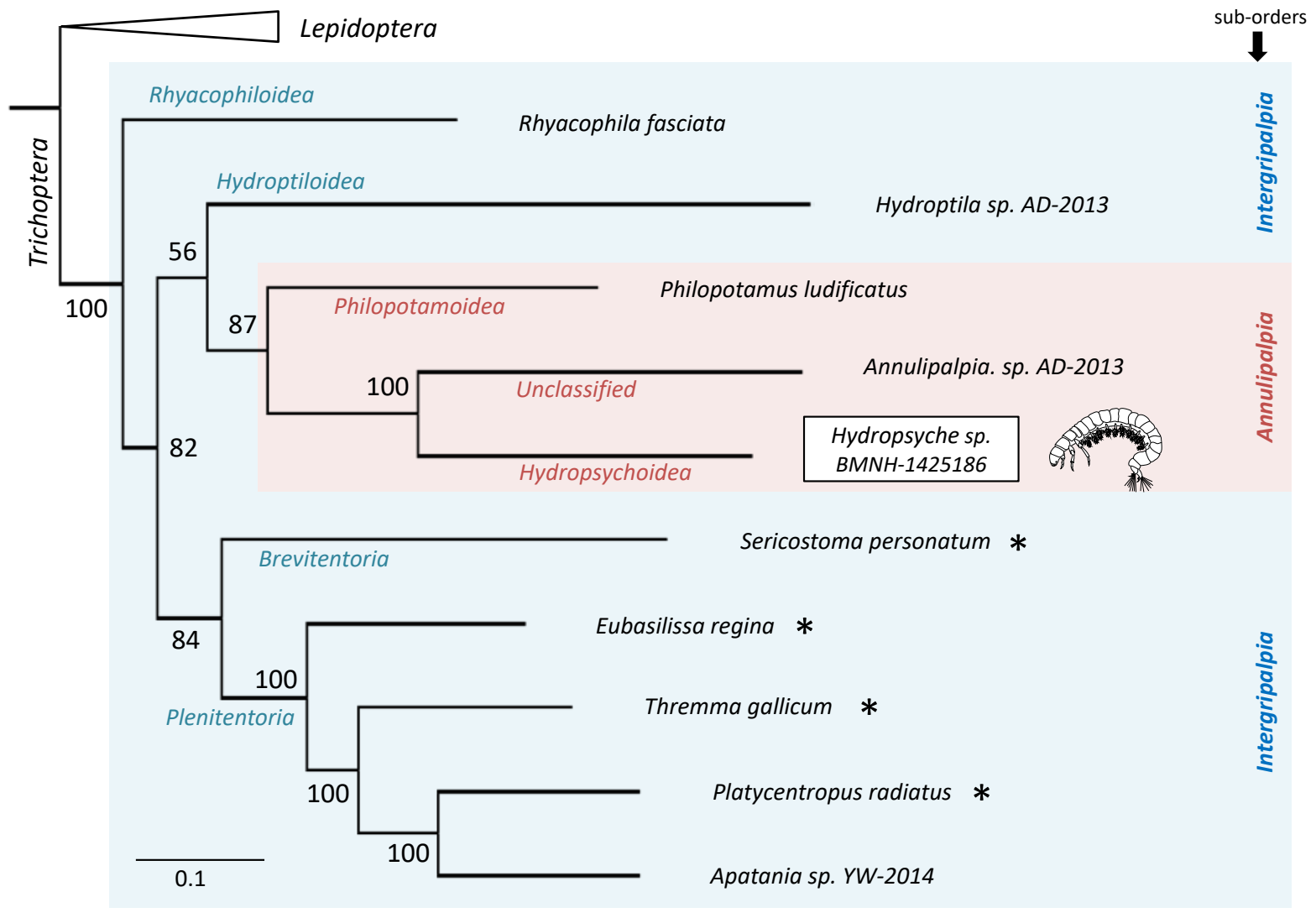

